\title{
A Research Note \\ Thiamin, Riboflavin, and Nicotinic Acid Contents of Tropical Root Crops from the South Pacific
}

\author{
J. H. BRADBURY and U. SINGH
}

\begin{abstract}
The thiamin, riboflavin, and nicotinic acid contents of sweet potato (Ipomea batatas, taro (Colocasia esculenta), giant taro (Alocasia macrorrhiza), giant swamp taro (Cyrtosperma chamissonis), taro (Xanthosoma spp), yam (Dioscorea alata and D. esculenta) were determined for fresh and $40^{\circ} \mathrm{C}$ dried material obtained from six South Pacific countries. Losses on drying at $40^{\circ} \mathrm{C}$ for $2-3$ days were $10-15 \%$ for the three vitamins. Sweet potato contained the largest amount of thia$\min (40-120 \mu \mathrm{g} / 100 \mathrm{~g}$ fresh weight) and along with Colocasia esculenta and Xanthosoma spp. the largest amounts of nicotinic acid. The root crops provided inadequate amounts of thiamin, riboflavin, and nicotinic acid with values ranging from 12-123, 12-59 and 220-1310 $\mu \mathrm{g} / 100 \mathrm{~g}$ fresh weight, respectively. Losses on cooking were about the same for all vitamins and root crops, with about a $20 \%$ loss on boiling (water retained) or baking and about a $40 \%$ loss on boiling (water discarded).
\end{abstract}

\section{INTRODUCTION}

THE LEVELS of total vitamin $C$ in tropical root crops were previously determined by Bradbury and Singh (1986). The thiamin, riboflavin and nicotinic acid of foods have been determined including losses during storage and processing (Dwivedi and Arnold, 1973; Girija ct al, 1982; Okoh, 1984; Gregory, 1984). The objective of this study was to determine the thiamin, riboflavin and nicotinic acid of cooked and uncooked tropical root crops from the South Pacific.

\section{MATERIALS \& METHODS}

\section{Materials}

Papain (type II), $\alpha$-amylase, (Type II), and phosphatase (type II) were obtained from Sigma Chem. Co. (St. Louis, Mo). Thiamin, riboflavin, nicotinic acid, cyanogen bromide, and other chemicals were reagent grade. Freshly harvested and weighed roots or stems were air freighted from the South Pacific and stored at $15^{\circ} \mathrm{C}$ for a short time before processing. Roots or stems were peeled, chopped and dried at $40^{\circ} \mathrm{C}$ to constant weight to determine moisture loss (Bradbury et al., 1984 , 1985). Duplicate analyses for vitamins were made on the dried samples. Fresh sweet potato and giant taro samples were peeled and divided into three parts, proximal, middle, and distal. From each part, two samples were taken from the periphery (2-3 mm beneath the skin) and a third sample from the center. These samples were analyzed and moisture determined at $40^{\circ} \mathrm{C}$.

For cooking $\sim 50 \mathrm{~g}$ cubes of root crop were heated in boiling water for 10,20 , and $30 \mathrm{~min}$. In one case the cooking water was discarded and in another it was retained and evaporated to dryness in the presence of the boiled sample which was then dried at $40^{\circ} \mathrm{C}$. Baking of $-50 \mathrm{~g}$ cubes was at $200^{\circ} \mathrm{C}$ in an oven for 15,30 , and $45 \mathrm{~min}$. Samples were dried at $40^{\circ} \mathrm{C}$ to constant weight and analyzed. A control sample was processed as above but without boiling and baking.

Author Bradbury is with the Chemistry Dept, Australian National Univ., Canberra, A.C.T., 2601, Canberra. Author Singh is Visiting Fellow at Australian National University on sabbatical leave from International Crop Research Institute for Semi Arid Tropics (ICRISAT). Current address: ICRISAT, Patancheru 502324, $A P$, India.

\section{Methods}

Thiamin. Fresh (about $4 \mathrm{~g}$ ) or dry (about $1.5 \mathrm{~g}$ ) material was homogenized in $40 \mathrm{~mL}$ of $0.1 \mathrm{M} \mathrm{HCl}$ for $3 \mathrm{~min}$ using a Polytron (Kinematica, GMBH, Switzerland). The mixture was heated for $1 \mathrm{hr}$ at $100^{\circ} \mathrm{C}$, cooled, and made to $50 \mathrm{~mL}$ with $0.1 \mathrm{M} \mathrm{HCl}$. After centrifugation at $10,000 \mathrm{~g}$ for $10 \mathrm{~min}, 10 \mathrm{~mL}$ supernatant was used for analysis. The AOAC (1980) method was used for oxidation. The solution was extracted with $20 \mathrm{~mL}$ isobutanol and its fluorescence was measured in a Perkin Elmer Model 512 fluorescence spectronreter in the excitation mode with excitation wavelength $370 \mathrm{~nm}$ and emission wave length $445 \mathrm{~nm}$.

In order to study the affect of enzyme extraction on thiamin estimation, the $0.1 \mathrm{M} \mathrm{HCl}$ extract after heat treatment was adjusted to $\mathrm{pH}$ 4.3 with $2 \mathrm{M}$ sodium acetate. An enzyme solution $(5 \mathrm{~mL})$ containing $100 \mathrm{mg}$ papain, $50 \mathrm{mg} \alpha$-amylase and $50 \mathrm{mg}$ phosphatase in $100 \mathrm{~mL}$ $1 \mathrm{M}$ sodium acetate buffer ( $\mathrm{pH} 4.3$ ) was added and incubated for $3 \mathrm{hr}$ at $38^{\circ} \mathrm{C}$. The mixture was heated at $100^{\circ} \mathrm{C}$ for $15 \mathrm{~min}$ to inactivate the enzymes and was processed as above. The enzyme blank was prepared in a similar way. Extraction in $1 \mathrm{M}$ sodium acetate $(\mathrm{pH} 4.3)$ for $16 \mathrm{hr}$ at $38^{\circ} \mathrm{C}$ instead of $0.1 \mathrm{M} \mathrm{HCl}$ was also studied in absence and presence of enzymic digestion.

Riboflavin. About $4 \mathrm{~g}$ fresh or $1.5 \mathrm{~g}$ dry material was homogenized in $40 \mathrm{~mL}$ of $1 \mathrm{M}$ sodium acetate buffer $(\mathrm{pH} 4.3)$ for $3 \mathrm{~min}$. The homogenate was heated for $1 \mathrm{hr}$ at $100^{\circ} \mathrm{C}$, cooled and made to $50 \mathrm{~mL}$ with distilled water. After centrifugation at $10,000 \mathrm{~g}$ for $10 \mathrm{~min}$, the clear supernatant was collected and $10 \mathrm{~mL}$ was used for analysis (AOAC, 1980). The fluorescence was measured with excitation wavelength $440 \mathrm{~nm}$ and emission wavelength $530 \mathrm{~nm}$.

Nicotinic acid. Fresh sample (about $5 \mathrm{~g}$ ) or dry powder (about $2.5 \mathrm{~g}$ ) was homogenized in $40 \mathrm{~mL}$ of $0.5 \mathrm{M} \mathrm{H}_{2} \mathrm{SO}_{4}$ for $3 \mathrm{~min}$. The mixture was refluxed for $1 \mathrm{hr}$, cooled and $\mathrm{pH}$ adjusted to 4.5 with $10 \mathrm{M} \mathrm{NaOH}$. The AOAC (1980) colorimetric method was followed.

\section{RESULTS \& DISCUSSION}

FOUR DIFFERENT PROCEDURES were compared for extraction of thiamin. Extraction of sweet potato and yam by acetate buffer ( $\mathrm{pH} 4.3$ ) alone gave $25-37 \%$ lower results than extraction with $0.1 \mathrm{M} \mathrm{HCl}$. Addition of enzymes increased the degree of extraction of sweet potato, but results were $10 \%$ lower than using $0.1 \mathrm{M} \mathrm{HCl}$. Additional treatment with enzymes after the $0.1 \mathrm{M} \mathrm{HCl}$ extraction, caused no increase in recovery of thiamin. With taro and giant taro, extraction was maximal in all cases. Thus, the extraction procedure with boiling $0.1 \mathrm{M} \mathrm{HCl}$ (no enzymes) was found satisfactory in all cases in confirmation of Gubler (1984).

Analysis of fresh samples of sweet potato, taro, and giant taro and the same samples after drying to constant weight at $40^{\circ} \mathrm{C}$ showed losses of about $15 \%$ of thiamin, $12 \%$ of riboflavin and $10 \%$ of nicotinic acid in the samples dried at $40^{\circ} \mathrm{C}$. These losses, which were outside experimental error, may have been due to decomposition on drying for 3 days at $40^{\circ} \mathrm{C}$, or perhaps due to inability to extract fully the vitamins from dried powder. Sun drying of Nigerian vegetables caused losses of thiamin and riboflavin, due to photochemical and heat degradation (Okoh, 1984).

Riboflavin was found to be constant across a sweet potato root and giant taro stem. Thiamin of sweet potato was twice as large $2-3 \mathrm{~mm}$ below the skin compared with the center and for giant taro it was $30 \%$ higher near the skin than at the center. 
Table 1-Thiamin (T), riboflavin (R), and nicotinic acid (N) content of tropical root crops from various South Pacific countriesa

\begin{tabular}{|c|c|c|c|c|c|c|c|c|c|}
\hline \multirow[b]{2}{*}{ Crops } & \multirow{2}{*}{$\begin{array}{c}\text { No. of } \\
\text { cultivars } \\
\text { per entry } \\
\end{array}$} & \multirow[b]{2}{*}{$\begin{array}{c}\text { Vitamin } \\
\text { analysed }\end{array}$} & \multicolumn{6}{|c|}{ Vitamin content from South Pacific countries } & \multirow{2}{*}{$\begin{array}{c}\text { Total } \\
\text { range } \\
\text { of values }\end{array}$} \\
\hline & & & $\begin{array}{c}\text { Papua } \\
\text { New Guinea }\end{array}$ & $\begin{array}{l}\text { Solomon } \\
\text { Islands }\end{array}$ & Tonga & Fiji & $\begin{array}{c}\text { Western } \\
\text { Samoa }\end{array}$ & Kiribati & \\
\hline Sweet potato & 3 & $\begin{array}{l}\mathrm{T} \\
\mathrm{R} \\
\mathrm{N}\end{array}$ & $\begin{array}{c}85(30) \\
25(2) \\
770(96)\end{array}$ & $\begin{array}{c}73(20) \\
41(13) \\
656(121)\end{array}$ & $\begin{array}{c}99(18) \\
27(6) \\
384(94)\end{array}$ & & & & $\begin{array}{rr}43 & 123 \\
19 . & 59 \\
259 & 887\end{array}$ \\
\hline $\begin{array}{l}\text { Taro } \\
\text { (C. esculenta) }\end{array}$ & 4 & $\begin{array}{l}T \\
R \\
N\end{array}$ & & $\begin{array}{l}37(22) \\
17(6) \\
678(368)\end{array}$ & . & $\begin{array}{c}35(13) \\
34(7) \\
932(268)\end{array}$ & $\begin{array}{c}25(6) \\
25(6) \\
671(205)\end{array}$ & & $\begin{array}{rr}15- & 71 \\
16- & 40 \\
268-1310\end{array}$ \\
\hline $\begin{array}{l}\text { Giant taro } \\
\text { Alocasia } \\
\text { macrorrihiza }\end{array}$ & 4 & $\begin{array}{l}T \\
R \\
N\end{array}$ & & & & & $\begin{array}{c}23(6) \\
20(6) \\
531(203)\end{array}$ & & $\begin{array}{rr}15- & 32 \\
12- & 29 \\
220- & 769\end{array}$ \\
\hline $\begin{array}{l}\text { Giant swamp taro } \\
\text { Cyrtosperma } \\
\text { chamissonis }\end{array}$ & 4 & $\begin{array}{l}T \\
R \\
N\end{array}$ & & & & & & $\begin{array}{c}25(19) \\
19(5) \\
463(112)\end{array}$ & $\begin{array}{rr}12- & 59 \\
12- & 26 \\
385- & 644\end{array}$ \\
\hline $\begin{array}{l}\text { Taro } \\
\quad \text { Xanthosoma spp. }\end{array}$ & 3 & $\begin{array}{l}T \\
R \\
N\end{array}$ & & & $\begin{array}{c}24(7) \\
28(8) \\
798(202)\end{array}$ & & & & $\begin{array}{rr}14- & 29 \\
25- & 36 \\
711-1078\end{array}$ \\
\hline $\begin{array}{l}\text { Yam } \\
\text { D. alata }\end{array}$ & 5 & $\begin{array}{l}T \\
R \\
N\end{array}$ & $\begin{array}{c}31(7) \\
24(7) \\
335(77)\end{array}$ & $\begin{array}{r}63(24) \\
36(10) \\
408(72)\end{array}$ & & & & & $\begin{array}{rr}23- & 90 \\
15- & 53 \\
245- & 490\end{array}$ \\
\hline $\begin{array}{l}\text { Yam } \\
\text { D. esculenta }\end{array}$ & 5 & $\begin{array}{l}\mathrm{T} \\
\mathrm{R} \\
\mathrm{N} \\
\end{array}$ & $\begin{array}{c}45(17) \\
26(3) \\
378(150) \\
\end{array}$ & $\begin{array}{c}44(11) \\
30(10) \\
450(147) \\
\end{array}$ & & & & & $\begin{array}{rr}24- & 72 \\
18- & 44 \\
251- & 691 \\
\end{array}$ \\
\hline
\end{tabular}

a Mean values (standard deviation in brackets) in $\mu \mathrm{g} / 100 \mathrm{~g}$ fresh weight. Cultivars of root crops used are as follows: Sweet potato (PNG) K-9, WMN, KO-2, (Sol. Is.) reef jimi, bugotu, dingale, (Tonga) tongamai, hawaii, halasika; Taro (Sol. Is.) PD-41, sasagiha, PD-1, PD-12, (Fiji) samoa normal, samoa hybrid, toakula, tausala ni samoa, (W. Samoa) niue, manua, fae'k'ele, pae'pae' Giant taro (W. Samoa) sega, toga, fui, niukini; Giant swamp taro (Kiribati) katuta red, ikarao red, ikarao green, atimainiku; Taro Xanthosoma spp. (Tonga) futuna, maheleuli, tea; Yam D, alata (PNG) takua yaimbi, du kupmi, yavovi, tolai, kpmora, (Sol. Is.) UL-5, toki, WCH-9, GU-147, A-172; Yam D. esculenta (PNG) mangilmu, glame, saikidi, kualika, martka, (Sol. Is.) fananiu, NGP-3, GUP-11, GUP-5, GUP-7.

There was no gradient of thiamin concentration from proximal to distal end in sweet potato or giant taro. No measurements were made for nicotinic acid.

The results in Table 1 are averages of analyses of 3-5 cultivars of a root crop from a particular country. Close examination of the data for each cultivar (not given in Table 1) failed to show any particular cultivars which contained consistently high levels of all three vitamins compared with others. In Table 1 , the thiamin content of sweet potato was significantly greater $(\mathrm{P}<0.01, \mathrm{t}$-test $)$ than that of the other root crops. The riboflavin content was not significantly different from one root crop to another, but taro ( $C$. esculenta) from Fiji contained significantly more riboflavin $(\mathrm{P}<0.05)$ than taro from Solomon Islands. Nicotinic acid was variable and was higher in taro and sweet potato $(\mathrm{P}<0.05)$ than in yam.

The values in Table 1 were made more meaningful by calculation of the amount of root crop that would be needed to supply the recommended daily allowance of thiamin $(1.4 \mathrm{mg})$, riboflavin $(1.6 \mathrm{mg})$ and nicotinic acid $(19 \mathrm{mg}$ ) (Davidson et al., 1979). The amount of fresh root crop required was within the range $1.6-8.4 \mathrm{~kg} /$ day. The adequacy of riboflavin was less than for thiamin and nicotinic acid in virtually all cases. Clearly, intake of these vitamins would need to be augmented from other sources.

The breakdown of vitamins on cooking increased with increase in the time of boiling or baking and the loss was independent of the type of root crop and of the vitamin measured. The loss of thiamin, riboflavin, and nicotinic acid averaged $20 \%$ (standard deviation, SD 6\%) after boiling for $20 \mathrm{~min}$ (water retained), 39\% (SD 9\%) (water removed) and 23\% (SD $6 \%$ ) after baking for $30 \mathrm{~min}$. Samples. were edible after 20 min boiling and $30 \mathrm{~min}$ baking. The approximate doubling of the vitamin loss on boiling if the water were discarded, was due to extraction of water soluble vitamins, as previously found with total vitamin C (Bradbury and Singh, 1986). The losses of the three vitamins are of the order of $20 \%$ on baking or on boiling (water retained) or $40 \%$ on boiling (water discarded) and may be compared with other heat treatment studies of these vitamins in sweet potato (Junek and Sistrunk, 1978), rice (Smirnova et al., 1982), legumes (Kilgore and Sistrunk, 1981; Soetrisno et al., 1982) and vegetables (Okoh, 1984).

\section{REFERENCES}

AOAC, 1980. "Official Methods of Analysis," 13th ed. Association of Official Analytical Chemists, Washington, DC.

Bradbury, J.H., Baines, J., Hammer, B., Anders, M., and Millar, J.S. 1984. Analysis of sweet potato from the Highlands of Papua New Guinea: relevance to the incidence of enteritis necroticans. J. Agric. Food Chem. 32: 469 .

Bradbury, J.H., Hammer, B., Nguyen, T., Anders, M., and Millar, J.S 1985. Protein quality and trypsin inhibitor content of sweet potato cultivars from the Highlands of Papua New Guinea. J. Agric. Food Chem. 33: 281 .

Bradbury, J.H. and Singh, U. 1986. Ascorbic acid and dehydroascorbic acid content of tropical root crops from the South Pacific. J. Food Sci. 51: 915.

Davidson, S., Passmore, R., Brock, J.F., and Truswell, A.S. 1979. "Human

Nutrition and Dietetics," p 176. Churchill Livingstone, Edinburgh.

Dwivedi, G.R. and Amold, R.G. 1973. Chemistry of thiamine degradation in food products and a model system. J. Agric. Food Chem. 21: 54

Girija, V., Sharda, D., and Pushpamma, P. 1982. Bioavailability of thiamin, riboflavin and niacin from commonly consumed green leafy vegetables in the rural areas of Andhra Pradesh in India. Int. J. Vit. Nut. Res. 52: 9 .

Gregory, J.F. 1984. Chemical changes in vitamins during food processing. Food Technol. 38: 51 .

Gubler, C.J. 1984. Thiamin. In "IIandbook of Vitamins: Nutritional, Biochemical and Clinical Aspects," Ch 6. L.J. Machlin (Ed), p. 245. Marcel Decker Inc., New York.

Junek, J. and Sistrunk, W.A. 1978. Sweet potatoes high in vitamin content but vitamin content is affected by variety and cooking method. Kansas Farm. Res. 27: 7 .

Kilgore, S.M. and Sistrunk, W.A. 1981. Effect of soaking treatments and cooking upon selected $B$ vitamins and the quality of blackeyed peas. $f$ Food Sci. 46: 909

Okoh, P.N. 1984. An assessment of the protein mineral and vitamin losses in sun-dried Nigerian vegetables. Nut. Rep. Int. 29: 359.

Smirnova, L.V., Khachaturora, T.N., Nekrasova, L.V., and Grigoreva, M.P. 1982. Effect of cooking methods on thiamin, riboflavin and niacin content of rice groats. Voprosy Pitainya (USSR) 2: 62 .

Soetrisno, U., Holmes, Z.A., and Miller, L.T. 1982. Effect of heating time on soybean on vitamin $B$, folacin retention and trypsin inhibitor activity. J. Food Sci. 47: 530

Ms received 1/26/86; revised 8/14/86; accepted 8/16/86.

This work is part of the ACIAR/ANU Program on Nutrition of Tropical Root Crops in the South Pacific financed hy the Australian Centre for International Agricultural in the South Pacific, financed hy the Alistralian Centre for international Agricultural Research (ACIAR). We thank the ICRISAT administration for granting sabbatical
leave to author Singh, Dr. G. Persley of ACIAR for support, collaborators in the South leave to author Singh, Dr. G. Persley of ACIAR for support, collaborators in the South
Pacific, viz. Drs. J. Wilson (Western Samoa) and M. Levett and M.F. Quin (Papua New Pacific, viz. Drs. J. Wilson (Western Samoa) and M. Levett and M.F. Quin (Papua New B. Ratieta (Kiribati) for providing samples of root crops and coworkers in our laboratory for assistance. 